\title{
Recent Books on Indonesian Manuscript
}

\author{
Dick van der Meij \\ Independent scholar \\ dickvandermeij2012@gmail.com
}

E.P. Wieringa and T. Hanstein (eds), Schrift Sprache/Aksara dan Bahasa. Ausstellungskatalog. Indonesische Handschriften der Staatsbibliothek zu Berlin Preußischer Kulturbesitz. Berlin: Staatsbibliothek zu Berlin-Preussischer Kulturbesitz/Jakarta: Museum Nasional Indonesia, 2015, 183 (in English) + 183 pp. (in Indonesian). (Paperback)

Farouk Yahya, Magic and Divination in Malay Illustrated Manuscripts. [Arts and Archaeology of the Islamic World Volume 6]. Leiden: Brill, 2016, $\mathrm{xx}+349$ pp. ISBN 9789004301641, price: EUR 136.oo (hardback); ISSN 22133844, ISBN 9789004301726, ISBN 978900430172-6 (e-book).

Sri Ratna Saktimulya, Naskah-Naskah Skriptorium Pakualaman Periode Paku Alam II (1830-1858). Jakarta: Kepustakaan Populer Gramedia, Ecole française d'Extrême-Orient, Perpustakaan Widyapustaka, Pura Pakualaman (Pustaka Hikmah Disertasi [PhD] XII), 2016, xvii + 438 pp. ISBN 9782855391991 (France); ISBN 9786024242282 (Indonesia), price: IRP 85.00O.

Karin Scheper, The Technique of Islamic Bookbinding. Methods, Materials and Regional Varieties. Leiden: Brill, 2015, xii +428 pp. [Islamic Manuscripts and Books 8]. ISSN 1879964, ISBN 9789004290921, price EUR 146.0O (hardback); 9789004291119, 143.00 (e-book).

Recently, four books were published that discuss a variety of aspects of Indonesian and Malay manuscripts and bookbindings. They deserve attention together as one discusses aspects that contribute to information provided in another. Two of them are in English, one in German and Indonesian while the fourth is in Indonesian. All four have been lavishly illustrated with many photographs showing the wide variety and beauty of these manuscripts. Collections have been used from Germany (Wieringa and Hanstein), Malaysia and Indonesia (Farouk Yahya), Yogyakarta, Central Java (Saktimulya) and Java

(C) DICK VAN DER MEIJ, 2017 | DOI: 10.1163/22134379-17304004

This is an open access article distributed under the terms of the prevailing CC-BY-NC license 
in general (Scheper). The focus of these books is on manuscripts as illustrated and physical objects, and the emphasis is therefore less on the texts they contain.

The German-Indonesian bilingual catalogue Schrift Sprache/Aksara dan Bahasa presents pictures of 46 manuscripts from Indonesia from the collection of the Staatsbibliothek zu Berlin Preußischer Kulturbesitz and is a welcome addition to the limited number of picture books about Indonesian manuscripts. The catalogue is divided into eight parts. The first part presents a number of stone inscriptions from the IV to XVI centuries written by Trigangga. The second part illustrates paper manuscripts in jawi (Arabic script adapted to Malay) by the hand of Edwin Wieringa as is the part that groups together the manuscript traditions of Java, Sunda (West Java), Bali, and Lombok on paper and palm leaf (lontar) in Javanese and Javanese-derived scripts. Part four, also by Wieringa, displays paper manuscripts from South Sulawesi written in Buginese and Makassarese script. Part five, by U. Kozok, takes the reader to manuscripts from the Batak area in North Sumatra inscribed on Batak tree bark and bamboo. Wieringa continues in part six with manuscripts from Lampung in South Sumatra on bamboo in Lampung script from South Sumatra, and part seven explores Chinese manuscripts. He ends the catalogue (part eight) with manuscripts in Latin script.

The catalogue starts with a brief introduction which chronicles the history of the Berlin collection where we learn of the main collectors: Johann Carl Schoemann (1806-1877), John Crawfurd (1783-1868), August Wilhelm von Schlegel (1767-1845), Sir Thoman Phillipps (1792-1872), Karl Bernhard von Sachsen-Weimar-Eisenach, and lastly Nicolaas Dirk Schuurmans (1838-19o8). On page 14 the authors state that manuscripts once owned by John Crawfurd $\left(1783^{-1868)}\right.$ are also in the Berlin collection but it remains unclear what manuscripts they are and unfortunately the publications the catalogue mentioned written by Phillipps are not included in the bibliography. Each manuscript is introduced, its origins are described, and a short description of its contents is added, which makes the catalogue more accessible to those unfamiliar with Indonesian manuscripts.

The history of the cataloguing of the manuscripts in the Berlin collection has been included in the introduction of this catalogue as well. The first catalogue was made by Schoemann of his own collection as early as 1851. A catalogue by Dietrich George and Hartmut-Ortwin Feistel from 1977 that is mentioned here and which was made to accompany an exhibition of Southeast Asian manuscripts is also unfortunately not to be found in the bibliography. This is a pity as it inspired the exhibition in Berlin in 2015, for which the present catalogue was compiled and published. 
Some remarks of an editorial nature should be made. It is a pity that no cross references have been made between manuscripts mentioned in the introduction and where they are to be found in the catalogue, while references have been made to the presentation in the exhibition. For instance, the old Javanese manuscript of the Dharma Pātañjala (Schoemann I 21) is referenced as being in showcase 6 but not that it is in the catalogue on pages $76^{-79}$, and some searching is needed to find the manuscripts mentioned in the introduction. I also do not understand why the bibliography was not put directly after the introduction. A list of manuscripts and their titles and shelf numbers would have been handy but perhaps too much for an exhibition catalogue like this.

Apart from these quibbles, the catalogue has been well produced and the photographs are beautiful and clear and give an accurate impression of what the manuscripts look like. Also the corresponding texts are clear and accessible to non-specialists.

Magic and Divination in Malay Illustrated Manuscripts studies images in Malay magic and divination manuscripts from the late eighteenth to early twentieth centuries, mostly from Malaysia but also from Indonesia. These little-studied illustrations, symbols, charts, diagrams, and tables are important because they add to our knowledge of Malay magic from a visual point of view. These images are integral parts of the magic and divination they explain and therefore should not be missed. The book looks at these images in relation to the text, to the general imagery of other Asian artistic traditions and in relation to texts in other languages than Malay. In doing so, the book wants to point at patterns of exchange between the various cultures that added to and helped decide on these images. Curiously, instead of proving that images are rare in Malay manuscripts, the opposite seems to be the case for this particular segment of the Malay manuscript tradition, which negates the Islamic injunction against depicting living beings (page 244). Moreover, the images prove that pre-Islamic culture and Islam not only co-existed but drew on each other's traditions to the benefit of both.

In his Conclusion, the author expresses the hope that he has succeeded in having 'contributed to increasing our knowledge and understanding of the artistic and textual aspects of the Malay manuscript tradition, as well as that of the Malay magical and divinatory practices' (p. 267). In my view, he has done so spectacularly. However, I have the impression that looking at traditions in mainland Southeast Asia, for instance the frequent references to Thailand, with the exclusion of some more use of manuscripts from Aceh and Minangkabau as 'beyond the purview of this book' (page 245), for example, may distort the picture somewhat. References to Javanese manuscripts have been made and illustrations of these manuscripts have indeed been included, but I don't 
understand why the large jump from Malaysia to Java was not seen as a problem while the much closer step to areas in Sumatra was seen as too far a leap. And comparisons have not been made consistently, which may also distort the picture. For example, on page 183 , the author points to the fact that images of the tiger are not very common in Malay magic and divination manuscripts, but if Java had been included for comparison in this particular issue we would see that in Javanese divination manuscripts, images of tigers are not rare at all.

In some cases, the conclusions drawn from these manuscripts are insufficiently supported by the evidence provided. For example, on page 206 the author states '[...] the employment of Arabic numbers in the squares as found in the Malay manuscripts places them as belonging to the Islamic corpus of talismanic designs.' When whole manuscripts have been written in Arabicderived jawi script, one might wonder what other kind of numerals might have been used and the fact that the numerals are Arabic would in my view not necessarily mean that they are Islamic designs. Similarly, on page 207 it is stated that the budụh magic square is not only used for talismans but also for divinatory purposes and thus that certain designs may be used in both magic and divination. This is curious as many examples may be found in the book of the use of illustrated expressions in different settings.

The remark on pages $214-215$ that 'there is often a strong relationship between illustrations and the ornamental motifs used in manuscript illumination' is important and deserves more research in the future, which I hope the author will consider. Especially for 'outsiders', these relations are often difficult to detect let alone to understand, as the book written by Sri Ratna Saktimulya (discussed below) expertly shows. Another important observation is found on page 239, where the author states that the lack of female involvement in the production and usage of magic and divination manuscripts could be seen as an extension of the situation in Malay literature in general. Although there is evidence of a literary tradition among Malay women, especially among the elite, records of written compositions and manuscript ownership by women are rare.' I think more detailed studies of the role of women in Southeast Asian literary traditions are overdue.

With no less than 308 illustrations and 11 tables, this is a reference work that will not be repeated for a long time to come. Illustrations other than from manuscripts have been wisely included, adding to our overall understanding of the position of manuscripts in a wider cultural setting. My conclusion is that an important step forward has been made in the study of Malay illustrated manuscripts. It has certainly opened my eyes. However, I believe there remains much to be done to substantiate the sometimes sweeping statements-which are inevitable in a work like this. 
Illuminations and illustrations in Javanese manuscripts have still not received the attention they deserve despite the availability of books like the catalogue discussed above, and thus many of the fascinating features of these adornments are still unknown or misunderstood. Sri Ratna Saktimulya's, Naskah-Naskah Skriptorium Pakualaman Periode Paku Alam II (1830-1858) represents a serious and in my view highly successful attempt to redress this deplorable situation for specific kinds of manuscripts from Central Java. In her book, she discusses the illustrations and illuminations in manuscripts made in the Pura Pakualaman in Yogyakarta under the rule of Paku Alam II (r. 183o1858). By doing this she opens up a totally new world of the interaction between illuminations and illustrations and the texts they accompany. The book is full of keen observations and explanations that will make the reader forever look at these manuscript features with another eye. One of the first such remarks is that in the period of the reign of Paku Alam II, many more illuminations were made in the Pura Pakualaman than in the palaces of the other principalities in Central Java of the Sultan of Yogyakarta, and the Susuhunan and Mangkunagara in Surakarta. This is an important observation as it shows that the cultural and artistic situations in these palaces differed with respect to literature and manuscripts. Another fascinating methodological aspect of her work is that she uses the literary texts (especially episodes in historical chronicles [ $\mathrm{babad}]$ ) produced in the Pakualaman as sources to understand the literary and manuscript situation in the Pakualaman. As far as I know, this has never been done with such astonishing detail. It appears from the manuscripts that the name of the patron of the production of the manuscripts (usually Paku Alam II) is often mentioned but not that of the scribe, author, or illustrator. However, from the sources that do mention their makers and comparisons with other manuscripts as to the kind of script used and other features, Mrs. Saktimulya has been able to assign the names of their makers to many otherwise anonymous manuscripts. She also found that the relations between the patron and the makers were intimate and that the prince oversaw the manuscript production process himself. Much information is provided about the authors, scribes, and illustrators who worked in the Pakualaman palace under Paku Alam II. From the manuscripts the author used as sources, it becomes clear why manuscripts were made at all, and the specific reasons they were made include instruction in ethics and morals as well as the preservation of stories and histories. In Mrs. Saktimulya's view, the illuminations in the manuscripts were made to help the readers understand and memorize the text. The relation between the paper that was used for the manuscripts and how the text was put on that paper, which changed over time, gives us insight into the workings of the manuscript production processes and also how this information may be used to date them. 
Illuminations may roughly be divided into three kinds: pěpadan (stanza and canto divides), rubrication (for indicating specific important elements within the text), rěrĕnggan (illustrations), and wĕdana (which may be subdivided into wĕdana rĕnggan and wĕdana gapura rĕnggan and consist of full page illuminations around a centred text block). Mrs. Saktimulya goes into astonishing detail to explain these different kinds of illuminations and illustrations from 18 manuscripts from the Pakualaman collection, all of which are meticulously described. The fact that she did not use manuscripts from the Pakualaman preserved in other collections in the world is a pity but probably due to practical reasons. It would be fascinating to see what she may come up with if she has the opportunity to expand the scope of her samples to the manuscripts from these other collections.

The book is written in Indonesian but in my view needs to be edited and translated in English for a wider international audience to ensure that Mrs. Saktimulya's important findings can be used for comparative purposes with other manuscript and text traditions by scholars unfamiliar with the Indonesian language.

The richly illustrated volume The Technique of Islamic Bookbindin: Methods, Materials and Regional Varieties by Karin Scheper opens the fascinating world of Islamic bookbinding and the restoration of these bookbindings. The book is written by a trained conservator of Western manuscripts currently employed at Leiden University Library, and this is exactly what makes the book so important. Her trained eye and conservationist experience is evident throughout the volume. Mrs. Scheper looks at books and manuscripts as material culture. A binding can tell much about the provenance of a book or of a manuscript, as much regional, temporal, and socio-cultural variety exists. In effect, book archaeology teaches us much more than just about books in the past. It teaches us about cultural connections and disconnections, changes in style and fashion, changes in appreciation of particular texts and ways of manuscript binding, the general attitude people may have had towards texts and books, and the economic aspect of manuscript and book trades. It is an integral part of the intellectual history of mankind.

The book consists of six chapters and takes the reader through an extensive assessment of the present knowledge on the subject in Chapter 1. Chapter 2 discusses the anatomy of the Islamic manuscript in great detail while Chapter 3 offers a comparative study of the historic sources and recent literature of the making of Islamic manuscripts. Chapter 4 is about the variety within the tradition of Islamic bookbinding and Chapter 5 maps the variations in time and place. Finally, Chapter 6 tells of considerations and new perspectives. 
The book is all-encompassing and it is thus a handbook of Islamic bookbinding. It does away with the old notion that Islamic bookbindings were inferior to Western bookbindings, a notion that proved detrimental to many old Islamic bookbindings because they were replaced by Western bindings, causing the irretrievable loss of much information. This brings me to one of the most compelling lessons from this book. Repairing a manuscript binding without meticulously recording each and every aspect of the original binding and thus what has been changed causes more scholarly damage than simply leaving the manuscript as it is. Another interesting notion to be mentioned here is that for the study of bookbindings, damaged manuscripts are indispensable. Precisely because bindings are damaged, researchers can have a look at the way they were made and form an idea of what the binding traditions encompassed. This may be an important lesson for manuscript collectors who work in library collections: do not only try to include beautiful undamaged manuscripts but acquire any manuscript you can because scholarship on manuscripts has now moved from mere text studies to the study of manuscripts/books as artifacts in themselves, as all four volumes discussed here attest.

In a way, the book is limited in scope as it only uses Islamic manuscripts from the collection of Leiden University Library, but her sample consists of hundreds of manuscripts, so it may be sufficiently comprehensive to offer a representative picture of the binding traditions in many places in the Islamic world. Since she states on page 344 that 'Southeast Asia stands out as the region with the most distinctive variant of the Islamic bookbinding tradition,' the few pages accorded to this tradition may seem a bit disappointing. This is especially true because the Malay world has the largest number of Muslims of any region on earth, and the manuscript tradition in this area is extremely well developed. The fact that the author limited herself to manuscripts from Southeast Asia that were written in Arabic script is also a point that I find hard to understand. Many leather-bound manuscripts from the Javanese tradition in Javanese script contain texts on Islam and not including them in the study simply because of the kind of script that was used seems odd, as does the apparent (and unwitting?) decision to consider Southeast Asian Muslim traditions to exist at the periphery of the Islamic World. It is to be hoped that the author has the opportunity to expand on this particular part of her subject in a later publication.

Although I understand that the Islamic bookbinding tradition has its own particularities, I am curious if this is specifically due to Islam or perhaps because of the areas where they stem from. I wonder if books on other subjects and written in other scripts from the same areas were indeed made differently and what this means for our understanding of the intellectual traditions and their mutual influencing in these areas. 
To conclude, four new books were published in a short time that push forward the world of manuscript and text studies. It proves yet again that philology and codicology attract scholars and publishers and inspire them to show the world what treasures are still awaiting further study. The new printing techniques that allow for illustrations to be included in books in numbers rarely seen before makes the results of these studies still more interesting and attractive, and can now much more easily visually show what in the old days had to be explained in words. 